\title{
Lidia Pacan-Bonarek
}

Uniwersytet Jana Kochanowskiego, Filia w Piotrkowie Trybunalskim

\section{Nazwy dzielnic i osiedli Tomaszowa Mazowieckiego}

\section{Wstęp}

Istnieje wiele opracowań dotyczących nazewnictwa miejskiego. Prace poruszają zarówno tematykę dotyczącą nazewnictwa ulic, placów, dzielnic, osiedli, jak również obiektów handlowych [m.in.: Borek 1984: 67-74; Borek 1979: 59-68; Buczyński 1962: 251-268; Handke 1970; Handke 1992; Handke 1998; Handke 2011; Kopertowska 1983: 204-215; Kopertowska 2001; Podracki 1978: 71-87; Zagórski 2008: 29-164]. Artykuł ten jest próbą uzupełnienia powyższej tematyki o nazwy dzielnic i osiedli Tomaszowa Mazowieckiego.

Materiał nazewniczy ${ }^{1}$, poddany analizie, wydobyty został z dokumentów znajdujących się w Archiwum Państwowym w Piotrkowie Trybunalskim Oddział Tomaszów Mazowiecki, Archiwum Głównym Akt Dawnych w Warszawie, Urzędzie Miasta Tomaszowa Mazowieckiego oraz z opracowań dotyczących omawianego terenu [220 lat Tomaszowa Mazowieckiego 2008; Góral, Kotewicz 1992; Kotewicz 1995; Dzieje miasta 1980].

Jak zauważa Mieczysław Buczyński „każde większe miasto, a nawet miasteczko, kształtowało się powoli, wchłaniając stopniowo okoliczne tereny i osiedla" [Buczyński 1962: 252]. W podobny sposób powstawał Tomaszów Mazowiecki znajdujący się w centrum Polski, nad rzeką Pilicą, 110 km od Warszawy i $55 \mathrm{~km}$ od Łodzi.

Tomaszów Mazowiecki² początkowo był niewielką osadą kuźniczą założoną przez Tomasza Ostrowskiego w 1788 r. nad rzeką Wolbórką, po tym jak odkryto na tym terenie pokłady rudy żelaznej [Góral, Kotewicz 1992: 15; Żebrowska 1980: zostały*.

${ }^{1}$ Zaznaczyć należy, że w materiale występują także nazwy już nieistniejące, które oznaczone

${ }^{2}$ Miasto to nazywane było również Tomaszowem Rawskim, Piotrkowskim, Fabrycznym i Brzezińskim [Góral, Kotewicz 1992: 15; Rosin 1980: 14; SGKP XII: 371], a także w związku z charakterem osady (wydobycie rudy) Tomaszów pierwotnie nazywany był Kuźnicami Tomaszowskimi [Rosin 1980: 14]. 
39; SGKP XII: 371-372]. Niestety, pokłady te okazały się niewielkie. W związku z zaistniałą sytuacją syn Tomasza Ostrowskiego, Antoni, w miejscu dawnej osady kuźniczej i na przyległych do niej terenach leśnych postanowił założyć nową osadę, której działalność związana miała być z tkactwem i handlem. Tomaszów rozwijał się prężnie i w 1824 r. uzyskał prawa osady fabrycznej i handlowej [SGKP XII: 372]. Od roku 1828 Antoni Ostrowski rozpoczął starania o nadanie praw miejskich, co nastąpiło w 1830 r. Akt erekcyjny Rady Administracyjnej Królestwa Polskiego z tegoż roku zatwierdził nazwę Tomaszów z dodatkowym określeniem Mazowiecki. Przez dwa wieki istnienia Tomaszowa Mazowieckiego rozszerzał on swoje granice, włączając kolejno przyległe tereny, wsie, osady (np. Białobrzegi, Gustek, Kępa, Nowy Port itd.). Obecnie Tomaszów Mazowiecki zajmuje powierzchnię $41,3 \mathrm{~km}^{2}$.

\section{Nazewnictwo Tomaszowa Mazowieckiego}

Analiza zebranego materiału nazewniczego została oparta na klasyfikacji przedstawionej przez Zygmunta Zagórskiego [Zagórski 2008: 36-40], który nazwy części Poznania podzielił z dwóch punktów widzenia: znaczeniowego i formalnego (strukturalnego), przyjmując nadrzędność klasyfikacji znaczeniowej [ibidem: 36]. W pierwszej z nich autor wyróżnił 10 ogólniejszych typów nazw:

1) nazwy topograficzne,

2) nazwy kulturowe,

3) nazwy pamiątkowe,

4) nazwy dzierżawcze,

5) nazwy etniczne,

6) nazwy służebne,

7) nazwy zawodowe,

8) nazwy rodowe i rodzinne,

9) nazwy patronimiczne,

10) nazwy relacyjne

oraz nazwy, które stanowią uzupełnienie powyższych typów: nazwy dwuznaczne, nazwy wieloznaczne, nazwy mieszane i nazwy niejasne. Z klasyfikacją znaczeniową nazw powiązany został podział na nazwy motywowane i niemotywowane [ibidem: 36, 38]. W związku z połączeniem klasyfikacji znaczeniowej i formalnej Z. Zagórski wyodrębnił poziom ogólniejszy, podstawowy (10 podanych powyżej typów) oraz poziom szczegółowy dotyczący charakterystycznych, indywidualnych cech badanej przestrzeni [ibidem: 36]. Biorąc pod uwagę stronę formalną, wydzielone zostały nazwy syntetyczne (wyrazy rdzenne, afiksalne, złożenia właściwe, zrosty ścisłe i luźne) i analityczne (wyrażenia przyimkowe, różnego rodzaju zestawienia oraz kombinacje zestawień i wyrażeń przyimkowych) [ibidem: 36, 39]. 
Analiza zebranego materiału nazewniczego występującego na terenie Tomaszowa Mazowieckiego przedstawia się następująco:

I. Nazwy topograficzne:

1. Nazwy topograficzne:

a) motywowane, syntetyczne:

Białobrzegi - od biały brzeg w formie liczby mnogiej, wtórnie zrostu [NMP I: 151];

Borek - od apelatywu borek 'mały las' [ibidem: 281];

Groty - od apelatywu grota ${ }^{3}$ 'wydrążenie w skale, jaskinia, pieczara' [SW I: 915] w liczbie mnogiej;

Kępa (dawniej także zapis Kępa Lazisko) - od apelatywu kępa 'pagórek na łące, trzęsawisku; wyspa na rzece lub jeziorze porośnięta krzewami' [NMP IV: 412];

Kopce - od apelatywu kopiec 'usypisko ziemi, wzniesienie, wzgórek, wyniosłość terenu; znak graniczny; szaniec' [NMP V: 126];

Laski - od apelatywu lasek w liczbie mnogiej [NMP VI: 17];

Niwka - od apelatywu niwa, niwka 'pole' [NMP VII: 460];

Podgórze - od apelatywu podgórze, a ta od wyrażenia przyimkowego pod góra [Zagórski 2008: 96];

b) motywowane, analityczne:

- nazwy będące zestawieniem:

Babi Dól - od gw. babi dót 'wąwóz, parów, jar' [NMP I: 46];

Pocieszna Góra - od apelatywu góra i przymiotnika pocieszny 'zdolny pocieszyć' [SW IV: 315];

- nazwy w postaci wyrażenia przyimkowego:

W Górach - od wyrażenia przyimkowego w górach;

2. Nazwy topograficzne z członem lokalizującym, motywowane, analityczne będące zestawieniem:

*Kępa Lazisko (dzisiaj Kępa) - od apelatywu kępa 'pagórek na łące, trzęsawisku; wyspa na rzece lub jeziorze porośnięta krzewami' [NMP IV: 412] oraz od nazwy miejscowej Łaziska, ta od apelatywu łazisko 'miejsce, gdzie poprzednio był łaz (las)' [NMP VI: 291];

Ląki Henrykowskie - od apelatywu łąka w liczbie mnogiej [ibidem: 307] i nazwy miejscowej Henryków, ta od imienia Henryk [NMP III: 475];

${ }^{3}$ W Nazwach miejscowych Polski pod red. K. Rymuta można odnaleźć Groty - od nazwy osobowej Grot [NMP III: 396]. Jednakże w Tomaszowie Mazowieckim w miejscu tak nazwanym istnieją Groty Nagórzyckie. Są to wyrobiska powstałe w wyniku eksploatacji piasku niezbędnego do produkcji szkła. 
II. Nazwy kulturowe

1. Nazwy kulturowe

a) motywowane, syntetyczne: "Baraki - od apelatywu baraki 'lekki budynek drewniany, buda; namiot, szałas płócienny' [SW I: 96] - jedna z pierwszych dzielnic Tomaszowa Mazowieckiego, którą zamieszkiwali ubodzy wyrobnicy, inna nazwa to Precz Bieda [Żebrowska 1980: 43];

b) motywowane, eliptyczne, analityczne: *Precz Bieda - jedna z pierwszych dzielnic Tomaszowa Mazowieckiego, którą zamieszkiwali ubodzy wyrobnicy, inna nazwa to Baraki [ibidem].

2. Nazwy kulturowe z członem lokalizującym

a) motywowane, analityczne: Wola Wiaderna - od apelatywu wola (mieszkańcy mogli być wolni od powinności wobec właściciela ziem) oraz nazwy miejscowej Wiaderno.

3. Nazwy kulturowe z członem pamiątkowym

a) niemotywowane, analityczne będące zestawieniami:

Osiedle 1000-lecia // Osiedle Tysiąclecia (potocznie nazywane Osiedle Niska - od nazwy głównej ulicy) - drugi człon związany z rocznicą powstania państwa polskiego;

*Osiedle 18-go Stycznia (dziś dzielnica Cekanów) - drugi człon upamiętniający datę wyzwolenia Tomaszowa Mazowieckiego;

*Osiedle XXXV-lecia PRL // Osiedle 35-Lecia PRL (dziś Osiedle Obrońców Tomaszowa z 1939 r.) - drugi człon związany z 35-leciem powstania PRL;

*Osiedle Armii Czerwonej (dziś Osiedle Wyzwolenia I) - drugi człon nadany na cześć Armii Czerwonej;

*Osiedle J. Krasickiego (dziś częściowo włączone do Śródmieścia) - drugi człon związany z osobą działacza komunistycznego Janka Krasickiego;

*Osiedle mjr. Hubala // Osiedle Hubala (dawniej Osiedle M. Nowotki // Osiedle Nowotki) - drugi człon upamiętniający Henryka Dobrzańskiego, pseud. Hubal, majora kawalerii Wojska Polskiego;

*Osiedle M. Nowotki // Osiedle Nowotki (dziś Osiedle mjr. Hubala) - drugi człon związany z działaczem ruchu robotniczego Marcelim Nowotką;

Osiedle Obrońców Tomaszowa z 1939 r. (dawniej Osiedle XXXV-lecia PRL // Osiedle 35-Lecia PRL) - drugi człon upamiętniający obrońców Tomaszowa Mazowieckiego w trakcie kampanii wrześniowej 1939 r.;

*Osiedle Waryńskiego (dziś Osiedle Górna) - drugi człon związany z polskim działaczem ruchu robotniczego Ludwikiem Waryńskim; 
*Osiedle Wojska Polskiego (dziś część Osiedla Śródmieście) drugi człon nazwy nadany na cześć polskich sił zbrojnych.

III. Nazwy dzierżawcze

1. Nazwy dzierżawcze, motywowane, syntetyczne:

a) z przyrostkiem -ów:

Cekanów - od nazwy osobowej Czekan [NMP II: 10, 208];

Józefów - od nazwy osobowej Józefów [NMP IV: 212, 214];

Ludwików - od nazwy osobowej Ludwik [NMP VI: 231];

Michałów - od nazwy osobowej Michat [NMP VII: 45];

Niebrów ${ }^{4}$ - od nazwy osobowej Niebor, z zanikiem -o- [ibidem: 378];

b) z przyrostkiem -ów + -k- (deminutywna): Michałówek ${ }^{5}$ - od nazwy osobowej Michat [ibidem: 45]; Rolandówka - od nazwy osobowej Roland ${ }^{6}$

c) z przyrostkiem -in (-yn): *Lusin - [Cudny 2006: 74; Żebrowska 1980: 44] od nazwy osobowej Lusza [NMP VI: 237, 407];

d) z przyrostkiem -izna: Borkowizna - od nazwy osobowej Borek lub Borkowski [NMP I: 290];

e) nazwy miejscowe dzierżawcze równokształtne z nazwą osobową: Kulas - od nazwy osobowej Kulas [NMP V: 464, 471], ta od apelatywu kulas 'noga; człowiek kulawy' [RymSEN I: 488]; Utrata - od nazwy osobowej Utrata', ta od utrata 'strata', też 'marnotrawstwo, rozrzutność', utracić [RymSEN II: 642].

IV. Nazwy etniczne, motywowane, syntetyczne: Nagórzyce - pierwotnie nazwa określała ludzi mieszkających na górze, później została przeniesiona na osadę [NMP VII: 336].

V. Nazwy rodowe, motywowane, syntetyczne: *Rawitów - od Rawity 'ten, który należy do rodziny herbu Rawicz ${ }^{8}$.

${ }^{4}$ Oficjalna nazwa Niebrowa to Osiedle Obrońców Tomaszowa z 1939 r.

5 Nazwę Michałówek można zaliczyć do nazw relacyjnych, deminutywnych, motywowanych i syntetycznych. Jednakże biorąc pod uwagę historię powstania tej dzielnicy (została ona tak nazwana od imienia dyrektora wilanowskiej fabryki sztucznego jedwabiu Michała Hertza - początki XX w.), zaliczam ją do nazwy dzierżawczych, motywowanych, syntetycznych. Natomiast nazwa Michałów pojawia się obok nazwy Michałówek dużo później i w innej lokalizacji (plany miasta z 1997 r. i 2007 r.), więc nie można tutaj mówić o relacji Michałów >Michałówek.

${ }_{6}^{6}$ Jest to obszar początkowo nazywany na cześć teścia (Rolanda) założyciela fabryki dywanów Aleksandra Millera [Pampuch 2012: 42].

${ }^{7}$ Nazwa ta powstała od nazwiska młynarza [Badziak 2008: 21; http://www.skansenpilicy.pl/ index. php?id= zrodla/3\&licz=0\&mr=0\&ml=zrodla, dostęp 22.10.2012]; por. nazwę rzeczną Utrata [Rieger, Wolnicz-Pawłowska 1975: 168].

${ }^{8}$ W Stowniku Geograficznym Królestwa Polskiego pod hasłem Tomaszów odnajdujemy informację: „Pod koniec zeszłego stulecia (około 1786 r.) miejsca te pokrywały lasy sosnowe i pola, będące własnością Tomasza Adama Ostrowskiego h. Rawicz, ówczesnego kaszt. czerskiego, a późniejszego prezesa senatu król. pols., dziedzica Ujazdu [...]” [SGKP XII: 371]. 
VI. Nazwy patronimiczne, motywowane, syntetyczne:

a) zprzyrostkiem -ic-: Starzyce-od nazwy osobowej Starzyc [SSNO V: 196].

VII. Nazwy relacyjne:

1. Nazwy relacyjne, przeniesione, motywowane:

a) syntetyczne: Bocian - nazwa przeniesiona od nazwy karczmy ,,Pod Bocianem" [Pampuch 2012c: 25; Żebrowska 1980: 44], ta od apelatywu bocian [RymSEN I: 43]; Karpaty - nazwa przeniesiona z nazwy gór Karpaty ${ }^{9}$ [NMP IV: 352]; Wilanów - nazwa przeniesiona z nazwy miejscowej Wilanów (dziś część Warszawy) ${ }^{10}$.

b) analityczne będące zestawieniami: Osiedle Cegielniana - od ul. Cegielnianej; Osiedle Górna - od ul. Górnej; Osiedle Kanonierów - od ul. Kanonierów; osiedle Niska - od ul. Niskiej - nazwa potoczna osiedla, urzędowa nazwa to Osiedle 1000-lecia; Osiedle Opoczyńska - od ul. Opoczyńskiej; Osiedle Parkowa - od ul. Parkowej; Osiedle Podleśna - od ul. Podleśnej; Osiedle Strzelecka od ul. Strzeleckiej; Osiedle Wierzbowa - od ul. Wierzbowej; Osiedle Zapiecek - od ul. Zapiecek; Osiedle Zielone // Osiedle Zielona - od ul. Zielonej.

2. Nazwy relacyjne, deminutywne, motywowane, syntetyczne: Brzustówka - od nazwy miejscowej Brzustów (ta od apelatywu brzost, brzostowy 'wewnętrzna, brunatna tkanka pęcherzowa kory brzozowej' [SpXVI II: 177]) [NMP I: 410]; Szymanówek - od nazwy miejscowej Szymanów (ta od nazwy osobowej Szyman, Szymon); Tomaszówek - od nazwy miejscowej Tomaszów (ta od nazwy osobowej Tomasz).

3. Nazwy relacyjne z członem lokalizującym, motywowane, analityczne będące zestawieniami: Wąwal-Kolonia // Kolonia Wąwal - od nazwy miejscowej Wawat (ta od formy z prefiskem ${ }^{*} q^{-}-+$wat, oznacza zapewne miejsce otoczone wałem [Wolff, Rzetelska-Feleszko 1982: 185]) i od apelatywu kolonia 'mała posiadłość ziemska, gospodarstwo rolne nadane właścicielowi po uwłaszczeniu, później osada lub gospodarstwo na gruntach przydzielonych w wyniku parcelacji, komasacji, migracji wewnętrznej' [NMP V: 56].

4. Nazwy relacyjne z członem kulturowym, motywowane, analityczne będące zestawieniami: *Tomaszówek Poduchowny - od nazwy Tomaszówek z członem kulturowym poduchowny 'dawniej należący do duchowieństwa’ [SW IV: 431], wskazującym na dawne stosunki własnościowe.

9 Być może nazwa ta została nadana dzielnicy ze względu na położenie na niewielkim wzniesieniu [Pampuch 2012c: 25].

${ }_{10}$ Nazwa Wilanów pochodzi od łacińskiego wyrażenia villa nova [Bijak 2001: 218]. 
5. Nazwy relacyjne z członem dyferencyjnym, motywowane, analityczne będące zestawieniami: Nowy Port - od apelatywu port oraz człon dyferencyjny nowy ${ }^{11}$; Stara Wieś - od apelatywu wieś oraz człon dyferencyjny stara; Osiedle Wyzwolenia I - od ul. Wyzwolenia z członem dyferencyjnym I; Osiedle Wyzwolenia II - od ul. Wyzwolenia z członem dyferencyjnym II.

VIII. Nazwy dwuznaczne

1. Dzierżawcze lub topograficzne, motywowane, syntetyczne: Gustek - od nazwy osobowej Gustek [RymSEN I: 285] lub według wcześniejszej formy zapisu Gozdek [Pampuch 2012b: 7] - od apelatywu gozdek 'mały las' [NMP III: 286]; Kaczka - od nazwy osobowej Kaczka ${ }^{12}$ lub od apelatywu kaczka [NMP IV: 239]; Piekło ${ }^{13}$ - od karczmy, która cieszyła się złą opinią i stąd jej nazwa Piekło lub od apelatywu piekto na określenie tego terenu, na którym funkcjonowały piece wapiennicze i smolarnie, z których wydobywały się dymy i ognie [Pampuch 2012a: 10].

\section{Wnioski}

Dominującym typem spośród 66 nazw obszarów ${ }^{14}$ są 23 nazwy relacyjne stanowiące $34,85 \%$ wszystkich typów. Następne typy toponimów to: 13 nazw topograficznych(19,67\%), 13 nazw kulturowych (19,67\%), 11 nazw dzierżawczych $(16,67 \%), 3$ nazwy dwuznaczne $(4,55 \%)$ oraz po jednym przykładzie $z$ nazw etnicznych $(1,51 \%)$, rodowych $(1,51 \%)$ i patronimicznych $(1,51 \%)$. Wśród urbonimów relacyjnych najliczniejsze są nazwy osiedli (56,53\%). Nazwy te składają się z dwóch członów. Pierwszego Osiedle ${ }^{15}$, który wskazuje na rodzaj wskazywanego obiektu, oraz drugiego, który pełni funkcję wyróżniającą [Bieńkowska, Umińska-Tytoń 2012: 198; Zagórski 2008: 34-35]. Wszystkie drugie człony wywodzą się od nazw ulic (np. Osiedle Strzelecka - od ulicy Strzeleckiej), czyli są nazwami pochodzącymi od innych nazw miejskich. Ciekawym przykładem wśród tych nazw jest osiedle Niska, gdyż jest to nazwa potoczna, którą posługują się mieszkańcy Tomaszowa, utworzona na wzór pozostałych toponimów występują-

${ }^{11}$ Toponim ten związany jest z nazwą Bocian, ponieważ karczma „Pod Bocianem” była między innymi karczmą flisacką, więc musiał znajdować się niedaleko niej port [Pampuch 2012c: 25].

12 Jan Pampuch mówi o młynie położonym nad rzeką Lubochenką, w którym mełł zboże młynarz o nazwisku Kaczka [Pampuch 2012a: 10].

${ }^{13}$ Można także spotkać się z drugą formą zdrobniałą Piekiełko określającą ten sam teren [Pampuch 2012a: 10].

${ }^{14}$ Terminu tego używam za Kwiryną Handke, która dzielnice i osiedla zaliczyła do ogólniejszej grupy nazwanej obszarami [Handke 1992: 66].

${ }_{15} \mathrm{~W}$ związku z przyjętą przeze mnie klasyfikacją człon Osiedle traktuję jako jeden z elementów nazwy danego obiektu. Wyjątek stanowi nazwa potoczna osiedle Niska. 
cych w tej grupie. Podobna sytuacja ma miejsce w przypadku urzędowo nadanej nazwy Osiedla Obrońców Tomaszowa z 1939 r, potocznie teren ten jest określany jako Niebrów. Pozostała część nazw zawierających człon Osiedle została zaliczona do nazw kulturowych z członem pamiątkowym. Określenia te mogą upamiętniać np. osoby (Osiedle Hubala), różnego rodzaju organizacje ( ${ }^{*}$ Osiedle Armii Czerwonej), daty, wydarzenia i rocznice historyczne (Osiedle 1000-lecia // Osiedle Tysiaclecia). Cechą charakterystyczną nazw z członem Osiedle jest redukcja w języku potocznym tegoż członu, np. Osiedle mjr. Hubala // Osiedle Hubala $\rightarrow$ Hubala. Redukcje te niestety bywają problematyczne w przypadku nazw osiedli należących do typu relacyjnego. W związku z motywacją od nazw ulic poprawna byłaby redukcja typu: Osiedle Cegielniana $\rightarrow$ Cegielniane, Osiedle Podleśna $\rightarrow$ Podleśne. Jednakże często można usłyszeć określenia zredukowane typu: na Niskiej, na Górnej, które są błędne i bez znajomości kontekstu mogą być zrozumiane jako nazwy ulic, a nie osiedli. Określenia osiedli występujących na terenie Tomaszowa Mazowieckiego stanowią 34,85\% wszystkich omawianych nazw.

Pozostała część toponimów $(65,15 \%)$ występujących na omawianym obszarze to nazwy dzielnic. Większość z nich początkowo była nazwami odrębnych jednostek terytorialnych, tj. wsi, osad ${ }^{16}$. Zachowały one swoją pierwotną postać formalną, np. wieś Brzustówka (SGKP I: 422) - od 1959 r. dzielnica miasta Brzustówka. Przeważającymi typami wśród urbonimów określających dzielnice są nazwy topograficzne $(30,25 \%)$, następnie dzierżawcze $(25,58 \%)$ oraz relacyjne $(23,25 \%)$. Pozostałe typy nazw potwierdza zaledwie kilka przykładów (nazwy kulturowe -3 nazwy $-6,98 \%$, nazwy dwuznaczne $-3-6,98 \%$, nazwy etniczne, rodowe i patronimiczne po 1 przykładzie, co stanowi 2,32\% wszystkich określeń dzielnic). Przypatrując się motywacji nazw topograficznych, można zauważyć odzwierciedlenie topografii terenu, na którym znajduje się miasto (np. Groty - obszar, na którym znajdują się groty, wyrobiska powstałe w wyniku wydobycia pisaku; Babi Dót znajduje się w dole, wąwozie; $W$ Górach - niewielkie wzniesienie). Nazwy dzierżawcze, których podstawą motywacji są nazwy osobowe, tworzone są głównie za pomocą sufiksów: -ów (45,46\%), -ów + -k- (18,18\%), -in (9,09\%), -izna $(9,09 \%)$. W tym typie toponimów występują także nazwy, które są równe nazwom osobowym $(18,18 \%)$. Trzecim typem określeń dzielnic, równie licznym jak pozostałe, są nazwy relacyjne, wśród których mamy do czynienia zarówno z nazwami syntetycznymi, jak i analitycznymi. Określenia analityczne zostały utworzone za pomocą: członu lokalizującego (Wąwat-Kolonia // Kolonia Wąwat), członu kulturowego (Tomaszówek Poduchowny), członu dyferencyjnego (Nowy Port).

16 Proces włączania poszczególnych wsi i osad w obręb Tomaszowa Mazowieckiego został przedstawiony w formie mapy w książce Waldemara Cudnego [Cudny 2006: 74]. Niestety, nastąpiły w tym zestawieniu kartograficznym pewne nieścisłości, np. w obręb miasta autor włączył wieś Wąwał, natomiast w rzeczywistości do Tomaszowa należy tylko jej część (stąd nazwa Wąwał-Kolonia). 
Najstarszą warstwą nazewnictwa miejskiego obszarów w Tomaszowie Mazowieckim są nazwy dzielnic, które początkowo były określeniami wsi, osad. Wraz $\mathrm{z}$ rozwojem miasta zostały one wchłonięte $\mathrm{w}$ jego granice. Proces ten miał podobny przebieg jak w innych tego typu ośrodkach na terenie Polski [Bieńkowska, Umińska-Tytoń 2012; Borek 1984: 67-74; Buczyński 1962: 251-268; Handke 1992; Handke 1998; Handke 2011; Kopertowska 1983: 204-215; Kopertowska 2001; Podracki 1978: 71-87; Zagórski 2008: 29-164]. Nazwy osiedli pochodzą dopiero z XX w. Jak można zauważyć, niektóre związane są z danym ustrojem politycznym (nieistniejące już dzisiaj nazwy: Osiedle Armii Czerwonej czy Osiedle 35-Lecia PRL).

Przedstawiona powyżej analiza urbonimów jest próbą zilustrowania mechanizmów, które towarzyszyły ich powstawaniu. Jednocześnie nazwy te ukazują związki toponimów z topografią regionu, kulturą materialną i duchową społeczeństwa Tomaszowa Mazowieckiego.

\section{Wykaz skrótow}

$\begin{array}{lrl}\text { NMP } & - & \text { Nazwy miejscowe Polski. Historia, pochodzenie, zmiany, Kazimierz Rymut (red.), } \\ & \text { t. I-VII, Kraków 1996-2007. } \\ \text { RymSEN }- & \text { Rymut Kazimierz, 1999, 2001, Nazwiska Polaków. Stownik historyczno-etymolo- } \\ & \text { giczny, t. I-II, Kraków. } \\ \text { SGKP }- & \text { Stownik Geograficzny Królestwa Polskiego i innych krajów słowiańskich, 1892, } \\ & \text { Bronisław Chlebowski (red.), t. XII, Warszawa. } \\ \text { SpXVI }- & \text { Stownik polszczyzny XVI wieku, Wrocław 1966 i nn. } \\ \text { SSNO }- & \text { Stownik staropolskich nazw osobowych, 1965-1987, Witold Taszycki (red.), t. I-VI, } \\ \text { SW } & \text { VII (Suplement) pod kierunkiem Marii Malec, Wrocław. } \\ - & \text { Stownik języka polskiego [tzw. warszawski], Jan Karłowicz, Adam Kryński, Włady- } \\ & \text { sław Niedźwiedzki (red.), t. I-VIII, Warszawa 1900-1927. }\end{array}$

\section{Bibliografia}

Badziak Kazimierz, 2008, Awans przemysłowy Tomaszowa Maz. do II wojny światowej i jego najważniejszy twórcy, [w:] Wiesława Bogurat, Andrzej Wróbel, Andrzej Kędzierski (red.), 220 lat Tomaszowa Mazowieckiego. Materiały z sesji naukowej, Tomaszów Mazowiecki, 21-30.

Bieńkowska Danuta, Umińska-Tytoń Elżbieta, 2012, Nazewnictwo miejskie Łodzi, Łódź.

Bijak Urszula, 2001, Nazwy miejscowe południowej części dawnego województwa mazowieckiego, Kraków.

Borek Henryk, 1979, Tendencje nazwotwórcze w nazwach osiedli mieszkaniowych, [w:] Jan Safarewicz (red.), Opuscula Polono-Slavica, 59-68.

Borek Henryk, 1984, Nazwy ulic i dzielnic Opola, „Kwartalnik Opolski” XXX/3, 67-74.

Buczyński Mieczysław, 1962, Nazwy dzielnic i przedmieść Lublina, „Rocznik Lubelski” V, 251268. 
Cudny Waldemar, 2006, Przemiany przestrzenne i funkcjonalne Tomaszowa Mazowieckiego w okresie transformacji ustrojowej, Łódź.

Góral Jan, Ryszard Kotewicz, 1992, Dwa wieki Tomaszowa Mazowieckiego. Zarys dziejów miasta 1788-1990, Tomaszów Mazowiecki.

Handke Kwiryna, 1970, Semantyczne i strukturalne typy nazw ulic Warszawy, Wrocław-Warszawa-Kraków.

Handke Kwiryna, 1992, Polskie nazewnictwo miejskie, Warszawa.

Handke Kwiryna, 1998, Stownik nazewnictwa Warszawy, Warszawa.

Handke Kwiryna, 2011, Dzieje Warszawy nazwami pisane, Warszawa.

Kopertowska Danuta, 1983, Nazwy osiedli mieszkaniowych oraz nazw placów i alei w miastach województwa kieleckiego, „Kieleckie Studia Filologiczne” 2, 204-215.

Kopertowska Danuta, 2001, Kielce. Historia i współczesność w nazewnictwie, Kielce.

Kotewicz Ryszard, 1995, Antoni Ostrowski 1782-1845. Ziemianin-przemystowiec, założyciel Tomaszowa Mazowieckiego, Warszawa.

Pampuch Jan, 2012, Tomaszów dzielnicowy, „Tomaszowski Informator Tygodniowy” 30 (1149), 42.

Pampuch Jan, 2012a, Tomaszów dzielnicowy, cz. 3, „Tomaszowski Informator Tygodniowy” 32 (1151), 10.

Pampuch Jan, 2012b, Tomaszów dzielnicowy, cz. 4, „Tomaszowski Informator Tygodniowy” 33 (1152), 7.

Pampuch Jan, 2012c, Tomaszów dzielnicowy, cz. 5, „Tomaszowski Informator Tygodniowy” 35 (1154), 25.

Podracki Jerzy, 1978, Językowe i historyczne podstawy nazw dzielnic oraz osiedli Warszawy, „Kronika Warszawy" IX, 3, 71-81.

Rieger Janusz, Wolnicz-Pawłowska Ewa, 1975, Nazwy rzeczne $w$ dorzeczu Warty, Wrocław-Warszawa-Kraków-Gdańsk.

Rosin Ryszard, 1980, Warunki naturalne i przeszłość okolic Tomaszowa Mazowieckiego do końca XVIII w., [w:] Barbara Wachowska (red.) Tomaszów Mazowiecki. Dzieje miasta, WarszawaŁódź, 14-38.

Wolff Adam, Rzetelska-Feleszko Ewa, 1982, Mazowieckie nazwy terenowe do końca XVI wieku, Warszawa.

Zagórski Zygmunt, 2008, Nazwy części miasta (dzielnic, osiedli, wsi, osad miejskich), [w:] Zygmunt Zagórski (red.), Nazewnictwo geograficzne Poznania. Zbiór studiów, Poznań 2008: 29-164.

Żebrowska Alojza, 1980, Rozwój przestrzenny miasta, [w:] Barbara Wachowska (red.), Tomaszów Mazowiecki. Dzieje miasta, Warszawa-Łódź, 39-74.

\title{
Lidia Pacan-Bonarek
}

\section{The names of districts and housing estates in Tomaszów Mazowiecki}

\author{
(Summary)
}

The article entitled The names of districts and housing estates in Tomaszów Mazowiecki is an attempt to complete the works and studies on city names in Poland. The analysis of proper names material was based on the meaning and formal names classification which allowed to separate the topographic names (Białobrzegi, Babi Dół), the cultural names (Baraki, Hubala housing estate), the possessive names (Cekanów), the ethnic names (Nagórzyce), the family names (Rawitów), the patronymic names (Starzyce), the relational names (Karpaty, Nowy Port) and the double meaning names (Gustek, Piekło). In each of the types one tried to separate the motivated names and unmoti- 
vated names, and synthetic names and analytic names, if they occurred. The most popular types of urbanonyms which occurred in the discussed area are the relational, topographic and cultural names. The application of semantic classification allowed to emphasise the relation between toponyms and land configuration, material and spiritual culture of the society of this region. Just like in the example of other cities the oldest group of city names of Tomaszów Mazowiecki are the district names which at the beginning had been the names of the villages and hamlets. When the towns developed the villages were absorbed by them.

Slowa kluczowe: toponimy, nazewnictwo miejskie, Tomaszów Mazowiecki.

Key words: toponyms, city names, Tomaszów Mazowiecki. 